\title{
Role of Competent Authority in Strengthening of Radiation Safety Infrastructure for Nuclear Medicine Facilities in Bangladesh
}

Md.Mofazzal Haider, Mehrun Nahar, Mustafizur Rahman, Amzad Hossain, Shahidul Islam, Shahana Afroz Bangladesh Atomic Energy Regulatory Authority

For Correspondence: Dr. Md. Mofazzal Haider, Head, Radiation Control Unit, Bangladesh Atomic Energy Regulatory Authority, E-12/A, Agargaon, Dhaka-1207, Telephone: 8801712008686, E-mail: mauntu2004@gmail.com.

\begin{abstract}
The peaceful use of radioactive sources/radiation generating equipment, in different areas, particularly in the medical sector contributes a lot in ensuring better quality treatment. The simple examples of beneficial application of radiation in the nuclear medicine are where radiation is being used for diagnosis and treatment of the patient. The misused or uncontrolled use of radiation can be a matter of serious concern for the human health in such kind of application. It is therefore essential to establish a stringent regulatory framework to avoid unwanted radiation exposure. According to International Atomic Energy Agency (IAEA) and national standard, every country should have an independent regulatory authority, which will maintain a process in order to control radiation related activities. In the present study, a comprehensive investigation is done on the nuclear medicine practices to assess the variations, which may happen in radiation safety situation due to the regulatory activities. The study is carried out including 5 nuclear medicine facilities, which are arbitrarily chosen, and their safety features are analyzed accordingly from the regulatory point of view. It is observed that at the outset of regulatory functions the radiation safety conditions of the facilities were not up to the level, as it was required by national and international standards. But the significant progress has been observed in the facilities within the couple of years after initiation of the regulatory program by the competent authority.
\end{abstract}

Keywords: Radioactive Source, Radiation Generating Equipment, Radiation Effect, Regulatory Authority, Radiation Safety Features, Legal Instruments.

\section{INTRODUCTION}

Radiation and radioactive substances are the part and parcel of the daily activities of human life. There is no other way to eliminate or restrict the radiation exposure entirely from the modern civilization. So, certain amount of risk is always associated with the radiation related activities. Therefore, the application of radiation requires proper justification. In nuclear medicine mostly unsealed sources of short half-lives are utilized such as Tc-99m, I-131, I-125 etc. F-18 (FDG) is the most common isotope used in PET/CT for which cyclotron is required to be established near the facility (1). Handling of radioactive substance in nuclear medicine comparatively safer than the other areas of medical discipline due to less activity and shorter half lives of isotopes. IAEA Basic Safety Standard (BSS 115) has defined some procedures in establishing legal and regulatory framework for ensuring safe and secure working environment in radiation facilities (2). First of all BSS 115 classifies the radiation exposure into the three categories such as occupational, medical and public exposures. The exposure, which is incurred at work and principally as a result of work, is defined as occupational exposure. The medical exposures, which are principally exposures of patients, receive during diagnosis or treatment and the public exposures comprise of all other exposures. According to IAEA and national standard, the requirements of fundamental radiation protection principle are desired to be followed during working with any sort of radioactive source or radiation generating equipment. Time, distance and shielding are the very basic requirements to reduce the individual exposure during working in the radiation zone. In 1960, International Commission on Radiological Protection (ICRP) developed dose limit for the occupational and the public to restrict the radiation effects but still there is no limit of exposure for the patients, rather guidance levels are available for them (3). In Bangladesh the radiation safety issue was taken up into account in the end of the 90s. At that time, Bangladesh Atomic Energy Commission 
(BAEC) took initiative with a view to develop a legal frame work for controlling the radiation related activities. On the basis of this effort Bangladesh government promulgated nuclear safety and radiation control (NSRC) act in 1993 and the corresponding NSRC rules in 1997 where the basic radiation safety requirements of BSS 115 have been incorporated $(4,5)$. At the same time BAEC was empowered by the section 4 of the NSRC act 1993 as a competent authority to oversee the radiation safety matters in the radiation facilities. There were many provisions in the act and rules from licensing to enforcement to strengthen the regulatory framework. But the NSRC act had also some limitations especially in handling of nuclear power plant, enforcement of law for example for any sort of violation punishment was so severe that it was quite impractical to apply in prevailing condition. This is why present government has promulgated new act to remove the deficiencies outlined in the old one and ensure nuclear and radiation safety in a superior way as well as to establish an independent regulatory authority (6). However, under the supervision of the then competent authority (BAEC) the regulatory activities were started immediately after the circulation of NSRC rules in 1997. In the beginning, nuclear safety and radiation control division of BAEC was assigned to carryout regulatory functions all over the country. It was flourished with manpower and other logistics to do such an overwhelming job. Primary task was specified to the scientists/engineers to collect information about the radioactive sources/radiation generating equipment. The first radiation survey was initiated on 15 May, 1999 and the radiation safety conditions observed at that time were simply alarming, some facilities even did not allow inspectors to carry out their job as it was assigned to them (7). The situation gradually started improving and regulatory inspections were performed from time to time in order to update the inventory and make the concerned people alert towards the radiation safety, which has been reflected in the post regulated scenarios of the radiation protection infrastructure of the facilities.

\section{MATERIALS AND METHODS}

A comprehensive inspection/re-inspection was carried out in each facility of the 5 nuclear medicine facilities of private and government sectors, which are located in the four divisional and one district city of central, southern and northern part of Bangladesh. An inspection checklist was prepared for the field survey. In this study Geiger Muller (GM) and scintillation type of radiation dose rate meters were utilized to investigate the radiation exposure emitted from the radioisotopes. Radiation dose level was recorded at different locations in and around the facilities. The specification of radioactive source/radiation generating equipment, room size, shielding condition of console area, wall, entrance door and the surroundings of the facilities were recorded in the checklist and together with these safety parameters a comprehensive layout of the room was also sketched on the spot. The checklist includes wide ranges of information from the personal protective equipment to shielding structure of the facilities. Accumulating all kinds of regulatory information an inspection report was produced putting some recommendations on the improvement of the radiation safety situation and afterwards re-inspection was performed to assess whether any changes happened to the facilities in respect of radiation safety matter. This type of regulatory activities is being framed as a continual process as per law to monitor radiation related activities, which ultimately help in improving the overall radiation safety scenario of the facility. In this study, findings of the inspection and reinspection with regards to shielding structure, radiation dose levels and other regulatory aspects are compared which have been presented in the different tables. 


\section{RESULTS AND DISCUSSIONS}

Table1 illustrates the radiation safety features before and after the commencement of the regulatory functions by the then nuclear safety and radiation control division (NSRC) of Bangladesh Atomic Energy Commission (BAEC). The radiation safety scenarios were studied on the 5 nuclear medicine facilities where one private facility was also included.

Table1. Comparison of regulatory requirements before and after commencement of regulatory activities (RA)

\begin{tabular}{|l|c|c|c|c|c|c|c|c|}
\hline $\begin{array}{l}\text { Name of } \\
\text { the Nuclear } \\
\begin{array}{l}\text { Medicine } \\
\text { Facilities }\end{array}\end{array}$ & $\begin{array}{c}\text { Radiation } \\
\text { Warning Sign }\end{array}$ & \multicolumn{2}{|c|}{$\begin{array}{c}\text { Area } \\
\text { Classification }\end{array}$} & \multicolumn{2}{c|}{$\begin{array}{c}\text { Source } \\
\text { Inventory }\end{array}$} & \multicolumn{2}{c|}{$\begin{array}{c}\text { Source Movement } \\
\text { Logook }\end{array}$} \\
\cline { 2 - 9 } & $\begin{array}{c}\text { After } \\
\text { RA }\end{array}$ & $\begin{array}{c}\text { Before } \\
\text { RA }\end{array}$ & $\begin{array}{c}\text { After } \\
\text { RA }\end{array}$ & $\begin{array}{c}\text { Before } \\
\text { RA }\end{array}$ & $\begin{array}{c}\text { After } \\
\text { RA }\end{array}$ & $\begin{array}{c}\text { Before } \\
\text { RA }\end{array}$ & $\begin{array}{c}\text { After } \\
\text { RA }\end{array}$ \\
\hline $\begin{array}{l}\text { NINMAS } \\
\text { Dhaka }\end{array}$ & $\mathrm{Y}$ & $\mathrm{Y}$ & $\mathrm{N}$ & $\mathrm{Y}$ & $\mathrm{Y}$ & $\mathrm{Y}$ & $\mathrm{N}$ & $\mathrm{Y}$ \\
\hline $\begin{array}{l}\text { INMAS } \\
\text { Khulna }\end{array}$ & $\mathrm{N}$ & $\mathrm{Y}$ & $\mathrm{N}$ & $\mathrm{Y}$ & $\mathrm{N}$ & $\mathrm{Y}$ & $\mathrm{N}$ & $\mathrm{N}$ \\
\hline $\begin{array}{l}\text { INMAS } \\
\text { Chittagong }\end{array}$ & $\mathrm{Y}$ & $\mathrm{Y}$ & $\mathrm{Y}$ & $\mathrm{Y}$ & $\mathrm{Y}$ & $\mathrm{Y}$ & $\mathrm{N}$ & $\mathrm{N}$ \\
\hline $\begin{array}{l}\text { INMAS } \\
\text { Dinajpur }\end{array}$ & $\mathrm{N}$ & $\mathrm{Y}$ & $\mathrm{N}$ & $\mathrm{Y}$ & $\mathrm{N}$ & $\mathrm{Y}$ & $\mathrm{N}$ & $\mathrm{N}$ \\
\hline $\begin{array}{l}\text { Nuclear } \\
\text { Medicine } \\
\text { Department } \\
\text { Lab Aid }\end{array}$ & $\mathrm{N}$ & $\mathrm{Y}$ & $\mathrm{N}$ & $\mathrm{Y}$ & $\mathrm{N}$ & $\mathrm{Y}$ & $\mathrm{N}$ & $\mathrm{N}$ \\
\hline
\end{tabular}

Table 2 shows the status of the safety accessories before and after starting of regulatory functions. According to this table, some progress has been made in respect to the availability of accessories especially lead apron, syringe shield, shielded workstation, but in case of radiation monitoring equipment contamination monitor, hand foot monitor is not available in any of the facilities under study. As per national and international standards these tools are obligatory for the nuclear medicine practice in order to monitor the contamination level both for the personal and the area of isotope handling.

Table 2. Comparison of safety accessories before and after commencement of regulatorv activities (RA)

\begin{tabular}{|c|c|c|c|c|c|c|c|c|c|c|c|c|}
\hline \multirow{2}{*}{$\begin{array}{l}\text { Name of } \\
\text { the Nuclear } \\
\text { Medicine } \\
\text { Facilities }\end{array}$} & \multicolumn{2}{|c|}{$\begin{array}{c}\text { Mobile Lead } \\
\text { Screen }\end{array}$} & \multicolumn{2}{|c|}{ Lead Apron } & \multicolumn{2}{|c|}{$\begin{array}{c}\text { Syringe } \\
\text { Shield }\end{array}$} & \multicolumn{2}{|c|}{$\begin{array}{c}\text { Shielded } \\
\text { Workstation }\end{array}$} & \multicolumn{2}{|c|}{\begin{tabular}{|c|}
$\begin{array}{c}\text { Contamination } \\
\text { Monitor }\end{array}$ \\
\end{tabular}} & \multicolumn{2}{|c|}{$\begin{array}{l}\text { Hand Foot } \\
\text { Monitor }\end{array}$} \\
\hline & $\begin{array}{l}\text { Before } \\
\text { RA }\end{array}$ & $\begin{array}{c}\text { After } \\
\text { RA }\end{array}$ & $\begin{array}{c}\text { Before } \\
\text { RA }\end{array}$ & $\begin{array}{c}\text { After } \\
\text { RA }\end{array}$ & $\begin{array}{c}\text { Before } \\
\text { RA }\end{array}$ & $\begin{array}{l}\text { After } \\
\text { RA }\end{array}$ & $\begin{array}{c}\text { Before } \\
\text { RA }\end{array}$ & $\begin{array}{l}\text { After } \\
\text { RA }\end{array}$ & $\begin{array}{c}\text { Before } \\
\text { RA }\end{array}$ & $\begin{array}{l}\text { After } \\
\text { RA }\end{array}$ & $\begin{array}{c}\text { Before } \\
\text { RA }\end{array}$ & $\begin{array}{l}\text { After } \\
\text { RA }\end{array}$ \\
\hline $\begin{array}{l}\text { NINMAS } \\
\text { Dhaka }\end{array}$ & $\mathrm{N}$ & $\mathrm{Y}$ & $\mathrm{Y}$ & $\mathrm{Y}$ & $\mathrm{Y}$ & $\mathrm{Y}$ & $\mathrm{Y}$ & $\mathrm{Y}$ & $\mathrm{N}$ & $\mathrm{N}$ & $\mathrm{N}$ & $\mathrm{N}$ \\
\hline $\begin{array}{l}\text { INMAS } \\
\text { Khulna }\end{array}$ & $\mathrm{N}$ & $\mathrm{Y}$ & $\mathrm{N}$ & $\mathrm{Y}$ & $\mathrm{N}$ & $\mathrm{N}$ & $\mathrm{N}$ & $\mathrm{N}$ & $\mathrm{N}$ & $\mathrm{N}$ & $\mathrm{N}$ & $\mathrm{N}$ \\
\hline $\begin{array}{l}\text { INMAS } \\
\text { Chittagong }\end{array}$ & $\mathrm{N}$ & $\mathrm{Y}$ & $\mathrm{Y}$ & $\mathrm{Y}$ & $\mathrm{N}$ & $\mathrm{N}$ & $\mathrm{N}$ & $\mathrm{N}$ & $\mathrm{N}$ & $\mathrm{N}$ & $\mathrm{N}$ & $\mathrm{N}$ \\
\hline $\begin{array}{l}\text { INMAS } \\
\text { Dinajpur }\end{array}$ & $\mathrm{N}$ & $\mathrm{N}$ & $\mathrm{N}$ & $\mathrm{Y}$ & $\mathrm{N}$ & $\mathrm{N}$ & $\mathrm{N}$ & $\mathrm{N}$ & $\mathrm{N}$ & $\mathrm{N}$ & $\mathrm{N}$ & $\mathrm{N}$ \\
\hline $\begin{array}{l}\text { Nuclear } \\
\text { Medicine } \\
\text { Department } \\
\text { Lab Aid }\end{array}$ & $\mathrm{N}$ & $\mathrm{Y}$ & $\mathrm{N}$ & $\mathrm{Y}$ & $\mathrm{N}$ & $\mathrm{N}$ & $\mathrm{Y}$ & $\mathrm{Y}$ & $\mathrm{N}$ & $\mathrm{N}$ & $\mathrm{N}$ & $\mathrm{N}$ \\
\hline
\end{tabular}

Table 3 demonstrates radiation-monitoring findings in the facilities. In table 3, each column provides two exposure values for inspection and re-inspection respectively. With regards to the dose levels, the patient waiting place and the isotope dispensing areas are major source of concern from the regulatory standpoint. In these areas maximum doses are recorded 50 and $170 \mu \mathrm{Sv} / \mathrm{h}$ respectively for which both the occupational and the public

Table 3. Estimated dose rates in $\mu \mathrm{Sv} / \mathrm{h}$ during inspection and re-inspection at different locations

\begin{tabular}{|c|c|c|c|c|c|c|}
\hline \multirow{2}{*}{$\begin{array}{l}\text { Name of } \\
\text { the Nuclear } \\
\text { Medicine } \\
\text { Facilities }\end{array}$} & \multicolumn{3}{|c|}{ Location 1, Gamma Camera Room } & \multirow{2}{*}{$\begin{array}{c}\text { Location } 4 \\
\text { Isotope } \\
\text { Dispensing } \\
\text { Room }\end{array}$} & \multirow{2}{*}{$\begin{array}{c}\text { Location } \\
5 \text { waste } \\
\text { Storage } \\
\text { Room }\end{array}$} & \multirow{2}{*}{$\begin{array}{c}\text { Location } \\
6 \text { Patient } \\
\text { Waiting } \\
\text { Place }\end{array}$} \\
\hline & $\begin{array}{c}\text { Around } \\
\text { Patient Bed }\end{array}$ & $\begin{array}{l}\text { Operator } \\
\text { Position }\end{array}$ & $\begin{array}{c}\text { Entrance } \\
\text { door }\end{array}$ & & & \\
\hline $\begin{array}{l}\text { NINMAS } \\
\text { Dhaka }\end{array}$ & 20,07 & $2,0.5$ & $2,0.25$ & 9,5 & $1.5,2$ & 50,20 \\
\hline $\begin{array}{l}\text { INMAS } \\
\text { Khulna }\end{array}$ & 10,03 & $1.5,0.25$ & $1,0.25$ & 03,08 & $5,0.25$ & 30,10 \\
\hline $\begin{array}{l}\text { INMAS } \\
\text { Chittagong }\end{array}$ & $4,0.25$ & $02,0.25$ & $0.25,0.25$ & 05,01 & $1.3,0.25$ & 50,06 \\
\hline $\begin{array}{l}\text { INMAS } \\
\text { Dinajpur }\end{array}$ & 12,10 & 02,01 & $0.25,0.25$ & 10,15 & 10,06 & 10,20 \\
\hline $\begin{array}{l}\text { Nuclear } \\
\text { Medicine } \\
\text { Department } \\
\text { Lab Aid }\end{array}$ & 20,10 & $02,0.3$ & $0.25,0.25$ & $170,14.5$ & 05,2 & $10,5.6$ \\
\hline
\end{tabular}

are vulnerable to radiation even though some facilities have developed patient waiting place with adequate shielding arrangement. It has been also observed that those worked in the isotope dispensing room do not wear lead apron for their personal safety, which is required especially during handling of gamma emitting isotopes. In other locations the estimated dose levels were found to be considerably reduced post inspection.

Figure.1 shows the assessment of radiation safety equipment available in 5 nuclear medicine facilities. Among the safety equipment, the availability of radiation dose rate meter (RDM), personal monitoring badge (TLD), mobile lead screen, contamination monitor (CM), electronic display in patient waiting place (EDPWP), electronic pocket dosimeter (EPD), shielded workstation (SW), lead eye glass (LEG), radiation monitoring during disposal (RMDD) etc are evaluated. For the occupational safety, some facilities introduces mobile 
lead screen (MLS) in the gamma camera room which is very encouraging step towards the implementation of NSRC rules although the vital regulatory demand radiation monitoring system is not yet established at the disposal point of liquid and gaseous wastes to the environment.

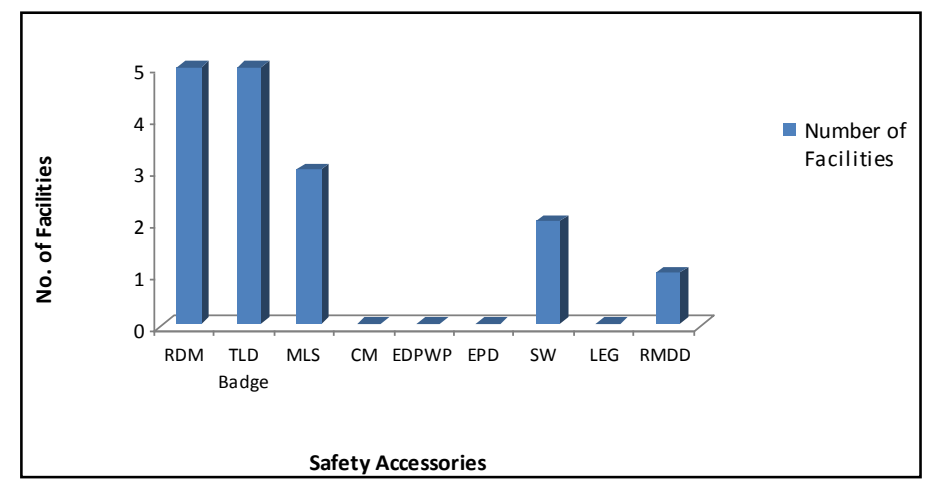

Figure 1: Assessment of radiation safety equipment in nuclear medicine facilities

Figure 2 describes the status of general regulatory requirements. None of the facilities has yet developed written local rule which is required by the national and international standards. Some facilities still do not have quality assurance program (QAP) and training program for the staff and the professional (TPSP) which are important as well. The recruitment of medical physicist is also a matter of concern in the nuclear medicine facilities where instead of qualified medical physicist (QMP) non trained scientific officer (SO) play the role of MP in few facilities (8).

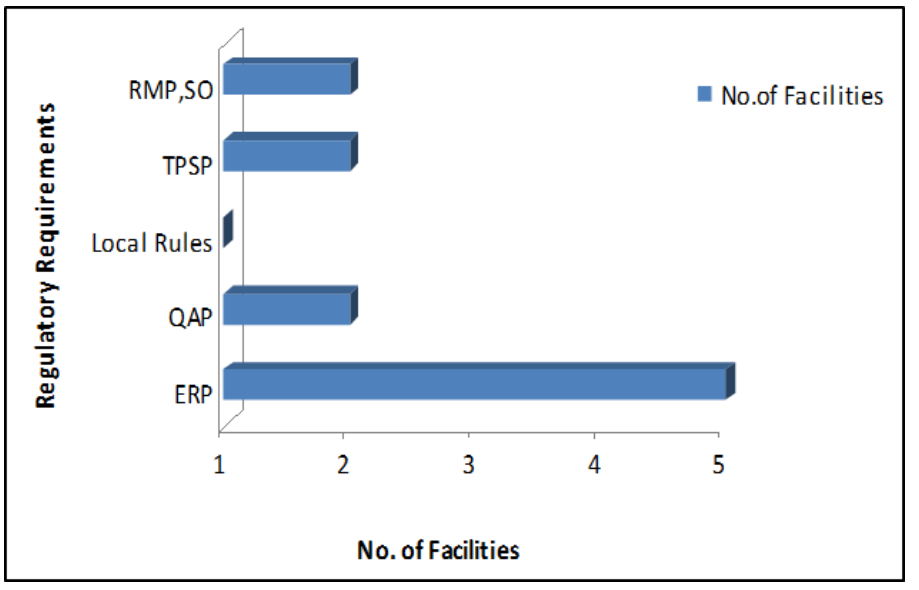

Figure 2: Assessment of general regulatory requirements in nuclear medicine facilities
In nuclear medicine various types of radioisotopes are utilized for diagnosis/treatment of the patient, research and quality control of equipment. Most of them are unsealed and some are sealed sources too. The physical state of the isotopes covers solid, liquid and gaseous as well. In nuclear medicine department it requires transporting of isotopes from one place to another. In this situation both safety and security of the sources are essential to take into account. Since liquid forms of isotopes are mostly utilized in nuclear medicine, therefore in the radiation survey, it is also necessary to carry out contamination monitoring before and after completion of the routine work. At the outset of the regulatory activities, it was found that due to lack of knowledge or awareness of radiation safety the entire radiation safety and security picture was very much below the standard.

According to table 1, significant improvement was observed in area classification by putting radiation warning signs and development of source inventory which were not convincing at all before starting of the regulatory process. In most of the facilities there were no register for the radiation sources at the primary stage of regulatory activities. But still a lot of work is required to be done from the regulatory side to maintain the source movement logbook which is very important element in order to ensure the safety and security of the sources.

\section{CONCLUSION}

Radiation safety is essential for the occupational workers, patient, public and the environment as well. In the current study considerable development has been observed from the initial status with respect to radiation safety aspects in the nuclear medicine facilities. The concerned people have been aware about the radiation protection and at the same time the changing attitude of people allowing regulatory functions in the facilities is really a remarkable progress towards the implementation of law and regulations. At Present, all the nuclear Medicine facilities are licensed from regulatory authority but 
the compliance levels is below the license renewal requirement even though the regulatory authority has issues several reminders to the concerned stakeholders. The described radiation safety situation in the current investigation still demands important and a lot of activities are needed to be performed from both the regulatory and users sides for implementing the national and international standards in order to ensure safe working environment for the concerned parties. The findings of the present investigation might have been more realistic if the study could have been done including large number of facilities executing the significant number of inspections by using several types of radiation dose rate meters. Eventually, it can be pointed out that in spite of all limitations and restrictions the newly developed independent regulatory authority (BAERA) has recognized the problem and has taken initiative in employing all the resources whatever is available to meet up the national demand on priority basis in securing human health from the undesired radiation exposure and hence to strengthen the overall radiation safety infrastructure of the country.

ACKNOWLEDGEMENT: The authors like to thank Bangladesh Atomic Energy Commission (BAEC) and Bangladesh Atomic Energy Regulatory Authority (BAERA) for providing logistics during the study. We are particularly grateful to the scientists/engineers of BAEC who helped us for completion of this work.

\section{REFERENCES:}

1. Madsen Mark T, Anderson Jon A, Halama James R, Kleck Jeff et al. AAPM Task group 108: PET and PET/CT shielding requirements. Med. Phys. 2006; 33: 5-1.

2. International Atomic Energy Agency (IAEA). International Basic Safety Standards for Protection Against Ionizing Radiation and For The Safety of Radiation Sources. Vienna, IAEA, Safety Series, No. 115, 1996.
3. International Commission on Radiological Protection (ICRP). Recommendations of the International Commission Radiological Protection, ICRP Publication 60, Pergamon Press, Oxford and New York 1991.

4. Republic of Bangladesh Government. Nuclear Safety and Radiation Control Act 1993 No. 21. Bangladesh Gazette 1993.

5. Republic of Bangladesh Government. Nuclear Safety and Radiation Control Rules-1997 (SRO No. 205-Law/97). Bangladesh Gazette 1997.

6. Republic of Bangladesh Government. Bangladesh Atomic Energy Regulatory Act 2012 No. 19 Bangladesh Gazette 2012.

7. Obaidul Awal, K, Mollah, A.S., Rahman, Samina, Haider,M Zoardar, A.K.M.Raushan, Ferdows, M, Islam, S. Regulatory report on survey-inspection of nuclear medicine practices in Bangladesh.NSRC-Vol.3/78/BD. 2002; 3: 1-5.

8. Obaidul Awal K \& Mollah A S M (2002). Regulatory Guide on Radiation Protection in nuclear medicine. Bangladesh atomic energy Commission Publication. NSRC-NM-G-01. 